This article was published as:

Bridge, T.C.L., Done, T.J., Beaman, R.J., Friedman, A., Williams, S.B., Pizarro, O., Webster, J.M., 2011. Topography, substratum and benthic macrofaunal relationships on a tropical mesophotic shelf margin, central Great Barrier Reef, Australia. Coral Reefs 30(1), 143-153. doi:10.1007/s00338-010-0677-3

The copyright owner is Springer.

The original publication is available at www.springerlink.com:

http://www.springerlink.com/content/412h90736x074666/ 


\title{
Topography, substratum and benthic macrofaunal relationships on a tropical mesophotic shelf margin, central Great Barrier Reef, Australia
}

\author{
Bridge, T.C.L. ${ }^{1}$ \\ Done, T.J. ${ }^{2}$ \\ Beaman, R.J. ${ }^{3}$ \\ Friedman, A. ${ }^{4}$ \\ Williams, S.B. ${ }^{4}$ \\ Pizarro, O. ${ }^{4}$ \\ Webster, J.M. ${ }^{5}$
}

${ }^{1}$ School of Earth and Environmental Sciences, James Cook University, Townsville, QLD 4811, Australia

${ }^{2}$ Australian Institute of Marine Science, PMB \#3, Townsville MC, QLD 4810, Australia

${ }^{3}$ James Cook University, PO Box 6811, Cairns, QLD 4870, Australia

${ }^{4}$ Australian Centre for Field Robotics (ACFR), University of Sydney, NSW 2006, Australia

${ }^{5}$ School of Geosciences, University of Sydney, Sydney, NSW 2006, Australia

Corresponding author:

thomas.bridge@jcu.edu.au

Ph: +61 747815283

Fax: +61 747815581

\begin{abstract}
Habitats and ecological communities occurring in the mesophotic region of the central Great Barrier Reef (GBR), Australia, were investigated using Autonomous Underwater Vehicle (AUV) from 51 to $145 \mathrm{~m}$. High-resolution multibeam bathymetry of the outer-shelf at Hydrographers Passage in the central GBR revealed drowned or submerged linear reefs with tops at 50,55, 80, 90, 100 and 130 m separated by flat, sandy inter-reefal areas punctuated by limestone pinnacles. Cluster analysis of AUV images yielded five distinct site groups based on their benthic macrofauna, with rugosity and the presence of limestone reef identified as the most significant abiotic factors explaining the distribution of macrofaunal communities. Reef-associated macrofaunal communities occurred in three distinct zones: (1) a shallow $(<60 \mathrm{~m})$ community dominated by photosynthetic taxa, notably scleractinian corals, zooxanthellate octocorals and photosynthetic sponges; (2) a transitional community (60 to $75 \mathrm{~m}$ ) comprising both zooxanthellate taxa and azooxanthellate taxa (notably gorgonians and antipatharians); and (3) an entirely azooxanthellate community (> 75 $\mathrm{m})$. The effects of depth and microhabitat topography on irradiance most likely play a critical role in controlling vertical zonation on reef substrates. The lower depth limits of zooxanthellate corals are significantly shallower than that observed in many other mesophotic coral ecosystems. This may be a result of resuspension of sediments from the sand sheets by strong currents, and/or a consequence of cold water upwelling.
\end{abstract}

Keywords: mesophotic, community structure, vertical zonation, AUV, Great Barrier Reef. 


\section{Introduction}

Mesophotic Coral Ecosystems (MCEs) are deep-fore-reef communities that generally occur from $~ 30 \mathrm{~m}$ to the bottom of the photic zone (Lesser et al. 2009; Kahng et al. 2010). They have been recorded in many locations throughout the tropics, including the Caribbean (e.g., Fricke and Meischner 1985), Enewetak (Colin 1986; Colin et al. 1986), Johnston Atoll (Maragos and Jokiel 1986), Hawaii (Grigg et al. 2002; Grigg 2006; Kahng and Kelley 2007), and the Red Sea (Fricke and Knauer 1986). Despite the low ambient light of the environment, MCEs generally contain zooxanthellate corals (e.g., Grigg 2006; Lesser et al. 2009; Kahng et al. 2010). Due to logistical and technological restrictions, information on both biotic and abiotic aspects of MCEs remains extremely scarce, particularly when compared with shallow-water coral reefs. Their nature is only beginning to be revealed through recent advances in scuba technology (closed-circuit rebreathers, mixed gases), robotics (Autonomous Underwater Vehicles and Remotely Operated Vehicles), and high-resolution multibeam bathymetric mapping. Recent studies of Indo-Pacific MCEs from Hawaii (Kahng and Kelley 2007) and American Samoa (Bare et al. 2010) using remotely operated vehicles (ROVs) show that MCEs provide important habitat for a large variety of species. While MCEs host many shallow-water species, they also contain a high number of depth-endemic species of fishes and invertebrates (Thresher and Colin 1986; Macintyre et al. 1991; Pyle et al. 2008).

On the Great Barrier Reef (GBR), submerged shelf-edge reefs, first identified by Harris and Davies (1989), occur almost continuously for at least $900 \mathrm{~km}$ along the GBR margin (Hopley 2006). Studies have been conducted on the geomorphology of shelf-edge reefs of the GBR (Harris and Davies 1989; Hopley et al. 1997; Hopley 2006) and their potential significance as archives of sea-level and climate fluctuation (Beaman et al. 2008); however, their ecology remains virtually unknown. Early observations of MCEs in the GBR were made in 1984 from a manned submersible to depths of $>200 \mathrm{~m}$ on the front of Ribbon Reef 5 (described in Beaman et al. 2008) and Myrmidon Reef (Hopley et al. 2007). Living scleractinian corals were recorded as deep as $115 \mathrm{~m}$ at Myrmidon Reef, with 100\% coral cover at 90 m (Hopley et al. 2007). Scoffin and Tudhope (1985) noted that rock outcrops at $70 \mathrm{~m}$ in the central GBR were colonised by "conspicuous alcyonarians, sponges, soft and stony corals”. Given these previous observations, and the evidence for widespread occurrence of MCEs in the Indo-Pacific, it is likely that the submerged reefs of the GBR could also provide habitat for extensive and diverse mesophotic communities. The aims of this study were therefore (1) to quantitatively describe the topography and substrates of a mesophotic reef habitat in the central GBR; (2) identify the benthic macrofaunal taxa and communities utilising those substrates; and (3) investigate the effect of abiotic variables on the distribution of benthic macrofauna.

\section{Study Area}

This study was part of a research cruise on the $R V$ Southern Surveyor undertaken in September-October 2007 to explore the outer-shelf of the GBR (Webster et al. 2008), and the study area is adjacent to Hydrographers Passage (19²0' S, $150^{\circ} 14^{\prime}$ E; Fig. 1 a). The outer-shelf in this area is characterised by a gently north-easterly sloping shelf edge margin which contains distinctive parallel reefs and terraces. The Hydrographers Passage region is subjected to particularly strong tidal currents. For example, the shallow-water reefs of the neighbouring Pompey Complex experience tidal currents in excess of $4 \mathrm{~m} \mathrm{~s}^{-1}$, the strongest in the 
GBR (Hopley 2006). The major oceanographic feature on the outer-shelf seaward of the GBR is the south-ward flowing East Australian Current (Church 1987).

\section{Materials and Methods}

Substrata, habitats, and communities were examined using a combination of multibeam swath mapping and high-resolution AUV imagery (digital still photographs). Multibeam sonar was used to map and identify important geomorphic features (e.g., reefs) to a depth of $200 \mathrm{~m}$. AUV imagery was used to define substrate composition and macrofaunal communities in 51 to $145 \mathrm{~m}$ depth. A single Conductivity-Temperature-Depth (CTD) cast was also taken at $19^{\circ} 38^{\prime} \mathrm{S}, 150^{\circ} 17^{\prime} \mathrm{E}$ to a depth of $216 \mathrm{~m}$ (Webster et al. 2008; Table 2).

\section{Bathymetry Data}

Multibeam bathymetry data were collected using a ship mounted Kongsberg ${ }^{\mathrm{TM}}$ Simrad EM-300 multibeam swath mapping system, which operated at a frequency of $30 \mathrm{kHz}$ and emitted a fanned arc of 135 beams per ping. Data were processed within Caris $^{\mathrm{TM}}$ HIPS/SIPS software to remove erroneous values and to apply appropriate corrections (e.g., tides and sound velocity), then gridded into a BASE (Bathymetry Associated with Statistical Error) surface at $5 \times 5 \mathrm{~m}$ resolution within HIPS/SIPS. The BASE surface pixel values were exported to ASCII XYZ (long/lat/depth) files, cropped to include $\leq 200 \mathrm{~m}$ depth (potential mesophotic habitat), and then imported into IVS3D Fledermaus ${ }^{\mathrm{TM}}$ for visualisation. ASCII files were also gridded within ArcGIS 9.3 to create XYZ-georeferenced raster layers for slope and depth. Depth values along the AUV transect were calculated from the multibeam data using the Spatial Analyst tool within ArcGIS 9.3. The total area mapped during the survey was $527 \mathrm{~km}^{2}$.

\section{AUV Data}

The University of Sydney's Australian Centre for Field Robotics provided the AUV "Sirius" for the study. Sirius collects a variety of physical and environmental data, including high-resolution stereo imagery, multibeam sonar, CTD, chlorophyll and turbidity (Williams et al. 2010). The AUV was programmed to travel at an altitude of $2 \mathrm{~m}$ above the seafloor at a speed of $\sim 0.45 \mathrm{~m} \mathrm{~s}^{-1}$. Pairs of stereo images were captured at 0.5 second intervals, which equates to a $\sim 1.5 \times 1.2 \mathrm{~m}$ image approximately every $22 \mathrm{~cm}$. The AUV mission on 10 October 2007 lasted approximately four hours and contained a total of 7260 image pairs. The transect was conducted down slope from 51 to $145 \mathrm{~m}$ water depth. The total length of the transect was $3620 \mathrm{~m}$. Georeferenced data collected by the AUV were converted into ArcGIS shapefiles and displayed in ArcMap 9.3.

\section{Data Analysis}

To collect data on biota and substrate, every twentieth image pair was examined ( $n=726$ ), providing a quadrat at $\sim 4.5 \mathrm{~m}$ intervals across the seafloor along the entire length of the transect $(3620 \mathrm{~m})$. Eight images were unusable because of poor image clarity, when the camera was either too close or too far from the seafloor to determine the composition of the image, resulting in a total of 718 images being used in statistical analysis. The relative abundances of macrofaunal taxa in each image, as well as five different substrate types (sand, gravel, rubble, sediment-covered 
limestone and limestone; Table 1) were graded following the percent cover criteria of Done (1982) and collated into matrices.

Taxa were identified to lowest taxonomic unit (LTU) in the original data collection. Because rare taxa can create unpredictable relationships with environmental variables (Clarke and Warwick 2001) rare related taxa were merged prior to statistical analysis (e.g., the zooxanthellate octocoral genera Sinularia, Sarcophyton and Lobotophytum were merged into the family Alcyoniidae). In some cases, functional groups were used to more accurately differentiate between taxa when identification of species or genus was not possible from the AUV images (e.g., fan gorgonian). The combination of taxa produced 27 categories of macrofauna for analysis.

Five site groups were identified using hierarchical cluster analysis based solely on their macrofauna (Ward's sum of squares index; group-average linkage, after Done 1982). Macrofauna data were collected on a relative abundance scale, therefore no further transformation of data were performed. Broad taxon classes were also generated in order to clearly illustrate the dominant type of taxa contributing to each site group. LTU identifications (where possible) and taxa included in taxon categories and broad taxon classes are shown in the Appendix. Multi-dimensional scaling was performed on a Bray-Curtis similarity matrix based on the relative abundances of macrofauna to explore relationships among site groups indicated by the cluster analysis.

The relationship between the relative abundance of macrofauna and abiotic variables (depth, rugosity, slope, aspect and the relative abundance of the five substrate types) was investigated using the BIOENV function within the statistical program PRIMER (see Clarke and Warwick 2001; and Clarke and Gorley 2006 for detail on methodology and justification). The strength and significance of the relationship between the Bray-Curtis similarity matrix (macrofauna), and a normalised Euclidean distance matrix based on the abiotic variables, was tested using Spearman rank correlation.

Depth values were derived from the multibeam bathymetry using ArcMap. Rugosity, slope and aspect were calculated using fine-scale triangular terrain reconstructions with centimetre resolution obtained from the AUV stereo images (Johnson-Roberson et al. 2010). Rugosity was calculated using a rugosity index by centring a window over each $1.5 \times 1.2 \mathrm{~m}$ image pair and dividing the area of the contoured surface contained within the window by the area of its orthogonal projection onto the plane of best fit (Friedman et al. 2010). The contoured surface area was the sum of the areas of the triangles that make up the surface, and the plane of best fit was found using Principal Component Analysis. Slope for each image referred to the smallest angle between the plane of best fit and the horizontal plane. Aspect referred to the direction that the plane faced, which was measured as the angle between north and the horizontal projection of the vector normal to the best fitting plane.

Shannon's diversity index $\left(\mathrm{H}^{\prime}=-\sum \mathrm{P}_{i}\left[\ln \mathrm{P}_{i}\right]\right.$ where $\mathrm{P}_{i}$ is the proportion of taxon $i$ contributes to the total score in any one image) was used as a measure of taxonomic diversity in each image. Continuous data ( $\mathrm{H}^{\prime}$, rugosity, and limestone) were smoothed by calculating five-point running means (generated by averaging a band of five integer scores using a gliding window across the 718 images) to better reveal dominant trends along the transect. All statistical analyses were performed on raw data. 


\section{Results}

\section{Topography}

The multibeam bathymetric mapping revealed a series of submerged reefs along the outer edge of the GBR shelf (Fig. 1 a). The submerged reefs closest to ( $\sim 12$ $\mathrm{km}$ from) emergent reefs (White Tip, Wyatt Earp and Rebe Reefs) form a semicontinuous line, rising from the seafloor at $~ 50 \mathrm{~m}$ depth to within 10 to15 m of the surface. The submerged reefs were separated by deeply incised channels, up to $80 \mathrm{~m}$ deep and 200 to $1000 \mathrm{~m}$ wide. Seaward of these reefs (referred to in nautical charts of the region as "shoals"), a series of at least six submerged reefs, most of which rose a few metres above the surrounding seafloor, had their crests at depths of $\sim 50,55,80$, 90, 100 and $130 \mathrm{~m}$ (Fig. 1 a). Some of these features were continuous throughout most of the study site, whereas others only occurred intermittently. The $50 \mathrm{~m}$ reef (not on the AUV transect) formed a semi-continuous feature throughout the study site, while the reefs at $55 \mathrm{~m}$ and $80 \mathrm{~m}$ (included in AUV transect) were relatively continuous in the southern section, but broken by several channels in the northern section (Fig. 1 a). The crests of both reefs were $\sim 300$ to $500 \mathrm{~m}$ apart, and the seafloor between them was stepped by numerous smaller terraces (Fig. 1 b). A $90 \mathrm{~m}$ reef occurred intermittently for about half the length of the study site including in the AUV transect (Fig. 1 b). A 100 m reef was present along almost the entire length of the study area, while a $130 \mathrm{~m}$ reef was well defined in the southern part of the study area, but more poorly defined in the AUV transect. The region between the $100 \mathrm{~m}$ and 140 m depth was composed of a relatively steep seafloor with a highly rugose topography (Fig. 1 b). The areas in between the reefs, identified as palaeo-lagoons by Webster et al. (2008), were flat and almost featureless. Above $100 \mathrm{~m}$ depth, they were punctuated by limestone pinnacles, interpreted as palaeo-patch reefs.

The substrate in the first $700 \mathrm{~m}$ of the AUV transect, which occurred on a topographic high at 50 to $75 \mathrm{~m}$ depth, was composed of a mixture of all five substrate types (Fig. 2). Seaward of the $80 \mathrm{~m}$ reef was a rhodolith field with $\sim 40 \%$ rubble (rhodoliths), 30\% gravel and 30\% sand. The rhodolith field gradually merged into a sand sheet at $\sim 90 \mathrm{~m}$ depth which extended for over $1000 \mathrm{~m}$. At its distal (seaward) edge it was punctuated by small limestone pinnacles, many of which were covered in sediment. At $90 \mathrm{~m}$ there was a reef composed predominantly of sediment-covered limestone, followed by another flat sandy expanse at $~ 100 \mathrm{~m}$ depth. Seaward of this sand flat, sand, gravel and rubble areas were interspersed with limestone blocks which rose up to five metres above the surrounding seafloor. Many of the limestone blocks were covered with sediment (visible in Fig. 5 b) with little or no bare limestone visible (Fig. 5 c). Although sediment-covered limestone occurred throughout the survey area, it was particularly abundant below $70 \mathrm{~m}$ depth. Beyond $140 \mathrm{~m}$ the substrate became flat and featureless, and was composed predominantly of sand and gravel.

\section{Macrobenthic Communities}

Cluster analysis of the benthic macrofauna yielded five distinct site groups. A summary of the major contributors to each site group is shown in Fig. 3, while the mean environmental properties, as well as diversity ( $\left.\mathrm{H}^{\prime}\right)$ are included in Table 2. Clusters 1 and 2 were found on soft, non-reef substrates ( $<5 \%$ mean limestone); clusters 3, 4 and 5 were reef-associated and contained significant amounts of limestone and sediment covered limestone. Cluster 1 was the most common, occurring in 54\% of images, and was defined by a paucity of macrofauna. It occurred 
in low relief areas with a sandy substrate. Cluster 2 (28\%) was also found on sandy substrates and exhibited low abundance of macrofauna, apart from colonies of the azooxanthellate octocoral Dendronephthya growing in the soft substrate. Cluster 3 (9\%) was dominated by azooxanthellate filter-feeders, particularly fan gorgonians. It was the dominant group on sediment-covered reefs below $75 \mathrm{~m}$ depth. Cluster 4 (3\%) was a transitional community composed of a mixture of photosynthetic taxa and filterfeeders. It occurred in areas of high slope with a high proportion of limestone and generally in depths from 60 to $75 \mathrm{~m}$. Cluster 5 (5\%) occurred on limestone and sediment-covered limestone substrates in the shallowest parts of the transect (depths $<60 \mathrm{~m}$ ) and was dominated by photosynthetic taxa, particularly zooxanthellate octocorals and the phototrophic sponge Carteriospongia. Multi-dimensional scaling of sites based on their macrofaunal assemblage showed site group clusters to be well defined by a 2-dimensional ordination (Fig. 4). The stress level of 0.12 indicated a good ordination, especially given the high number of samples $(n=718)$.

Vertical zonation of reef-associated macrofaunal communities was clearly evident in the AUV transect and occurred in three distinct zones (Fig. 6). Photosynthetic taxa were dominant on the reef top above $60 \mathrm{~m}$ depth (Fig. $7 \mathrm{a}$ ), with communities composed of zooxanthellate octocorals such as Cespitularia and Alcyoniids, a diverse assemblage of scleractinia including Acropora, Montipora, Pocillopora and Seriatopora, and Carteriospongia. From 60 to $75 \mathrm{~m}$ a transitional community occurred, comprising both photosynthetic and non-photosynthetic filterfeeding taxa. Fan gorgonians and antipatharians became more abundant (Fig. 3), while the dominant zooxanthellate taxa were encrusting and platey scleractinia such as Leptoseris and Echinophyllia. Below 75 m, photosynthetic taxa became extremely rare, with reef communities dominated by a diverse suite of azooxanthellate octocorals, including Annella, Chironepthya, Siphonogorgia, Echinogorgia, Zignisis and Ellisellids, both branching (e.g., Ellisella) and non-branching (Junceella, Viminella).

Diversity (H') was highest on steep, rugose reef habitats $<75 \mathrm{~m}$ depth (Fig. 7 b). Diversity on the rugose reef habitats in 95 to $120 \mathrm{~m}$ was significantly higher than non-reef areas, but lower than on shallower reefs $<75 \mathrm{~m}$. Non-reef substrates contained low diversity; however the sand sheets did contain the giant (up to $10 \mathrm{~cm}$ diameter) benthic foraminifera Cycloclypeus carpenteri. Although it was not included as part of the macrofauna, it was relatively abundant (up to $10 \mathrm{~m}^{-2}$ in the AUV images) between 80 and $100 \mathrm{~m}$ depth. Significant spikes in diversity were observed in association with high limestone and rugosity values (Fig. 8). The BIOENV analysis indicated that the abiotic variables rugosity and limestone best explained the variation observed in the relative abundance of benthic macrofauna among sites (Spearman rank correlation $=0.755)$. Rugosity had the strongest individual correlation $(0.734)$.

\section{Discussion}

\section{Topography and Substrata}

The submerged reefs at Hydrographers Passage appear to be part of an extensive and diverse but poorly characterised reef environment on the GBR outershelf. High-relief areas are built of reefal material and surrounded at their bases by rubble originating from the reefs. Large areas devoid of topographic highs allow the development of extensive sand sheets. Interestingly, a significant proportion of the reef limestone was covered in sediment, similar to that described from the deep reef slope at Enewetak by Colin et al. (1986). Strong currents in the region probably disturb the sand sheets, resuspending sediments and transporting them onto the reefs. 
The magnitude and periodicity of sediment transport onto the reefs may play an important role in determining community structure in several ways, discussed below, however it is difficult to speculate on the periodicity of these events and, consequently, how often limestone reefs may be free from sediment.

\section{Controls on depth zonation and community structure}

Substrate type clearly plays an important role in determining the distribution of benthic macrofaunal communities at Hydrographers Passage. Diversity of both photosynthetic and filter-feeding benthic macrofauna at all depths was significantly higher on reef substrates than inter-reefal areas. However, other factors such as slope angle, habitat microtopography and oceanography also appear to play an important role in the determining community structure.

Reduced irradiance with depth eventually limits the distribution of photosynthetic taxa (Kirk 1994), and consequently depth is an important determinant of community structure on MCEs (Kahng et al. 2010). Reef communities at Hydrographers Passage exhibited strong depth zonation (Fig. 6), with the transition from communities dominated by photosynthetic taxa to filter-feeders; probably reflecting decreased irradiance with depth. Various studies (e.g., Brakel 1979; Ohlhorst and Liddell 1988; Liddell et al. 1997; Lesser et al. 2009) have shown that areas of high slope receive significantly lower levels of irradiance than horizontal surfaces. High slope may occur at different scales; large, steep walls obviously exhibit high slope, however microhabitat topography can also cause a significant reduction in irradiance (Ohlhorst and Liddell 1988). The method used to calculate rugosity and slope used in this study (see Friedman et al. 2010) ensured that rugosity and slope were independent. However, because both values were calculated over the same scale (1.5 x $1.2 \mathrm{~m})$, an image may contain a topographically complex microhabitat (high rugosity), but low overall slope. Biologically, the effect is the same - high slope, regardless of scale, causes a reduction in irradiance which is probably the critical determinant in limiting the occurrence of photosynthetic taxa. On mesophotic reefs where irradiance is already significantly reduced by depth, relatively small increases in slope angle may be sufficient to affect community composition. Mean slope and rugosity values in sites dominated by photosynthetic taxa $\left(6^{\circ} \pm 6\right.$ for slope and $1.12 \pm$ 0.07 for rugosity) are substantially lower than in the transition zone $\left(21^{\circ} \pm 13\right.$ and 1.24 $\pm 0.16)$ or on the deeper reefs $\left(22^{\circ} \pm 18\right.$ and $\left.1.31 \pm 0.23\right)$ (Table 2). Although the exponential decrease in irradiance with depth is of obvious importance to photosynthetic taxa, slope angle also appears to play an important role in determining vertical zonation.

In some cases, rugosity values derived from AUV images may be amplified by living frame-building macrofauna (such as branching Scleractinia or fan gorgonians) growing on the antecedent limestone framework. Nonetheless, it is clear that topographically complex reef habitats exhibit higher diversity than flatter areas. Moreover, the shallow, photosynthetic site group exhibits relatively low rugosity but high diversity of macrofauna, including frame-building taxa such as Scleractinia. This indicates that despite the potential influence of living frame-builders on rugosity values, there is a clear correlation between overall rugosity of the substrate and high macrofaunal diversity.

The influence of slope angle at Hydrographers Passage is well illustrated by examining the community composition of scleractinian corals. Although corals in intermediate depths (12-24 m) are often most abundant on steep slopes less prone to sediment accumulation, reduced irradiance on steep slopes can cause coral 
recruitment to shift to horizontal substrates in deeper water (Bak and Engel 1979; Birkeland et al. 1982). At Hydrographers Passage, the low-slope habitat on top of the $55 \mathrm{~m}$ reef contained the highest diversity of scleractinian corals, including branching species of Acropora, Pocillopora, and Seriatopora. Steeper areas in 60 to 75 m, contained much lower coral diversity, and were inhabited by flat, platey and encrusting forms such as Echinophyllia and Leptoseris. Colonies were typically dark in colour, suggestive of high zooxanthellae densities needed to meet energy requirements in low light (Fricke et al. 1987). Both genera are common inhabitants of MCEs in the Indo-Pacific (Kahng et al. 2010), indicating adaptation to light-limited environments, while their plating morphology and tendency to occur on vertical walls (Veron 2000) suggests they are susceptible to high sedimentation. The greater light availability on low slope reef tops therefore favour branching corals, which are better able to deal with sediments, while the steeper areas favour species adapted to utilise limited irradiance.

The AUV transect reveals scleractinia to be rare below $75 \mathrm{~m}$ at Hydrographers Passage, despite Leptoseris spp. being known to occur at depths well over $100 \mathrm{~m}$ elsewhere in the Indo-Pacific (e.g., Kahng and Kelley 2007; Maragos and Jokiel 1986; Fricke et al. 1987). Abundant Leptoseris (100\% cover) was recorded at Myrmidon reef, only $340 \mathrm{~km}$ north-west of Hydrographers Passage, at $90 \mathrm{~m}$ depth (Hopley et al. 2007). Therefore, it is likely that local environmental and substratum conditions such as exposure to moving sediments are responsible for the shallow depth limit of Leptoseris at Hydrographers Passage, rather than insufficient surface irradiance. Although very high turbidity associated the extreme tides and currents are known to affect coral communities on shallow water reefs near Hydrographers Passage (Kleypas 1996; van Woesik and Done 1997), they are probably not important on MCEs that occur $>15 \mathrm{~km}$ seaward of the emergent reefs. The dominant oceanographic feature in this area, the East Australian Current, brings clear, oceanic water to the mesophotic reefs, while data collected by the AUV during the transect indicated relatively low turbidity ( $0.5 \mathrm{NTU}$ ). Therefore, sediments derived from the GBR lagoon would be unlikely to cause the shallow depth limit of scleractinian corals observed at Hydrographers Passage. However, the prevalence of sediment-covered limestone in the AUV transect indicates that localised currents may transport autochthonous sediments from the sand sheets to the reefs, particularly on the reefs seaward of the sand sheets $(>75 \mathrm{~m})$. Resuspension of sediments could affect the community composition in two ways: (1) by increasing turbidity near the seafloor, thereby reducing light penetration; and, (2) by smothering corals and inhibiting growth. Small amounts of sediment would probably be sufficient to exclude many of the flat, plating or encrusting corals which occur on MCEs.

Although azooxanthellate, filter-feeding octocorals were abundant on sediment-covered limestone reefs, they were generally concentrated along steep walls and the edges of reef crests - environments least likely to accumulate sediment. Liddell et al. (1997) showed sediment cover in low-slope habitats limited the diversity and abundance of benthic taxa on deep reefs (200 to $250 \mathrm{~m}$ depth) in the Bahamas, resulting in "small islands of suitable habitat surrounded by a desert of barren sand". A similar pattern is seen in Figure 5 a, which shows a diverse community of octocorals occurring on the steep crest of a reef, with low octocoral abundance away from the crest. Although reduced irradiance would not affect such taxa, they do appear to be negatively impacted by sediment accumulation, though not to the same extent as scleractinia. 
Upwelling onto the GBR shelf at Hydrographers Passage, affecting both nutrient availability and temperature, may also play a role in determining community structure. Chlorophyll data collected by the AUV during the transect revealed chlorophyll levels up to $0.6 \mu \mathrm{g} \mathrm{l}^{-1}$ at $100 \mathrm{~m}$ depth, significantly higher than the $\sim 0.2 \mu \mathrm{g}$ $\mathrm{I}^{-1}$ at the sea surface. Octocorals are suspension feeders whose diet consists primarily of phytoplankton and other small $(<20 \mu \mathrm{m})$ organic particles (Fabricius et al. $1995 \mathrm{a}$, 1995 b). Unlike Scleractinia, which possess highly developed stinging cells (nematocysts) ideal for zooplankton capture, octocorals contain few small nematocysts and rely on currents to provide nutrition. Current speed has been shown to affect food intake and growth rates in soft corals, with food intake highest at unidirectional, intermediate flow speeds (8-15 cm ${ }^{\mathrm{s}-1}$; Fabricius et al. $1995 \mathrm{a}, 1995 \mathrm{~b}$; Fabricius and Alderslade 2001). Increased levels of chlorophyll would represent a significant advantage for azooxanthellate octocorals, particularly phytoplanktonfeeders such as Dendronephthya and may explain the abundance of azooxanthellate soft corals at Hydrographers Passage, particularly below $70 \mathrm{~m}$. Data collected both by the AUV and the CTD cast suggest a thermocline may also exist at $\sim 70 \mathrm{~m}$, with temperature $25.5^{\circ} \mathrm{C}$ at the surface, $24.5^{\circ} \mathrm{C}$ at $70 \mathrm{~m}$ and falling to $18.5^{\circ} \mathrm{C}$ at $140 \mathrm{~m}$. Low temperature has been shown to limit coral growth on mesophotic reefs in Palau, where wide daily temperature fluctuations (commonly $\sim 10^{\circ} \mathrm{C}$, up to $20^{\circ} \mathrm{C}$ ) resulting from large internal waves were implicated in the depauperate biological community on reef slopes from 60 to $120 \mathrm{~m}$ (Wolanski et al. 2004). These data only represent a "snapshot", and unfortunately no long-term data exist for the region. However, the shift in community composition coinciding with observed thermocline depth suggests upwelling may also play a role in determining community structure.

In summary, the GBR at Hydrographers Passage contains an extensive mesophotic ecosystem composed of diverse reef and inter-reefal communities. The distribution of benthic macrofauna is closely correlated with rugose, limestone reef habitats, with different macrofaunal communities inhabiting reef and non-reef substrates. There is a distinct vertical zonation of macrobenthic communities occurring on mesophotic reefs, with photosynthetic taxa dominating above $60 \mathrm{~m}$ depth, a transitional zone between 60 to $75 \mathrm{~m}$, and a community dominated by azooxanthellate filter-feeders from 75 to $140 \mathrm{~m}$ depth. This study provides the first quantitative assessment of a mesophotic ecosystem within the GBRMP, and, with 900 $\mathrm{km}$ of shelf edge reefs in the central GBR alone, the first insight into a potentially vast mesophotic ecosystem.

\section{Acknowledgements}

We acknowledge the captain and crew of the $R V$ Southern Surveyor for their outstanding work on the cruise. The project was funded by the Australian Marine National Facility, the Integrated Ocean Observing System, the National Geographic Society, the Natural Environment Research Council, the Great Barrier Reef Marine Park Authority's Science for Management Awards, and the School of Earth and Environmental Science, James Cook University. Robin Beaman acknowledges a Queensland Smart Futures Fellowship for salary support. We would like to thank Katharina Fabricius and Chris Battershill at the Australian Institute of Marine Science and Carden Wallace, Paul Muir and Patricia Sutcliffe at the Queensland Museum for assistance with the taxonomy. We also gratefully acknowledge Adella Edwards for her help with preparing the figures, and Ari Stypel, Alex Brazenor, Scott Hansen and Michael Kramer for their valuable assistance. 


\section{References}

Bak RPM, Engel MS (1979) Distribution, abundance and survival of juvenile hermatypic corals (Scleractinia) and the importance of life history strategies in the parent coral community. Mar Biol 54: 341-352

Bare AY, Grimshaw KL, Rooney JJ, Sabater MG, Fenner D, Carroll B (2010) Mesophotic communities of the insular shelf at Tutuila, American Samoa. Coral Reefs 29: 369-377

Beaman RJ, Webster JM, Wust RAJ (2008) New evidence for drowned shelf edge reefs in the Great Barrier Reef, Australia. Mar Geol 247: 17-34

Brakel WH (1979) Small-scale spatial variation in light available to coral reef benthos: quantum irradiance measurements from a Jamaican reef. Bull Mar Sci 29: 406-413

Birkeland C, Rowley D, Randall RH (1982) Coral recruitment patterns at Guam. Proc $4^{\text {th }}$ In Coral Reef Symp 1: 339-344

Church JA (1987) East Australian Current adjacent to the Great Barrier Reef. Aust J Mar Freshw Res 38: 671-683

Clarke KR, Warwick RM (2001) Changes in Marine Communities: An Approach to Statistical Analysis and Interpretation. PRIMER-E, Plymouth

Clarke KR, Gorle, RN (2006) PRIMER v6: User Manual/Tutorial. PRIMER-E, Plymouth

Colin PL (1986) Benthic community distribution in the Enewetak Atoll lagoon, Marshall Islands. Bull Mar Sci 38: 129-143

Colin PL, Devaney DM, Hillis-Colinvaux L, Suchanek TH, Harrison III JT (1986) Geology and biological zonation of the reef slope, 50-360 m depth at Enewetak Atoll, Marshall Islands. Bull Mar Sci 38: 111-128

Done TJ (1982) Patterns in the distribution of coral communities across the central Great Barrier Reef. Coral Reefs 1:95-107

Fabricius KE, Alderslade P (2001) Soft corals and sea fans: a comprehensive guide to the tropical shallow-water genera of the central-west Pacific, the Indian Ocean and the Red Sea. Australian Institute of Marine Science, Townsville, Australia

Fabricius KE, Benayahu Y, Genin A (1995a) Herbivory in asymbiotic soft corals. Science 268; 90-92

Fabricius KE, Genin A, Benayahu Y (1995b) Flow-dependent herbivory and growth in zooxanthellae-free soft corals. Limnol Oceanogr 40: 1290-1301 
Fricke HW, Meischner D (1985) Depth limits of Bermudan scleractinian corals: a submersible survey. Mar Biol 88: 175-187

Fricke HW, Knauer B (1986) Diversity and spatial pattern of coral communities in the Red Sea upper twilight zone. Oecologia 71: 29-37

Fricke HW, Vareschi E, Schlichter D (1987) Photoecology of the coral Leptoseris fragilis in the Red Sea twilight zone (an experimental study by submersible). Oecologia 73: 371-381

Friedman A, Pizarro O, Williams SB (2010) Rugosity, slope and aspect from bathymetric stereo image reconstructions. Proceedings of the IEEE Oceans 2010 Conference, Sydney, Australia, pp 9

Grigg RW (2006) Depth limit for reef building corals in the Au'au Channel, S.E. Hawaii. Coral Reefs 25: 77-84

Grigg RW, Grossman EE, Earle SA, Gittings SR, Lott D, McDonough J (2002) Drowned reefs and antecedent karst topography, Au'au Channel, S.E. Hawaiian Islands. Coral Reefs 21: 73-82

Harris PT, Davies PJ (1989) Submerged reefs and terraces on the shelf edge of the Great Barrier Reef, Australia: morphology, occurrence and implications for reef evolution. Coral Reefs 8: 87-98

Hopley D (2006) Coral Reef growth on the shelf margin of the Great Barrier Reef with special reference to the Pompey Complex. J Coast Res 22: 150-158

Hopley D, Graham TL, Rasmussen CE (1997) Submerged shelf-edge reefs, coral reefs, Great Barrier Reef Australia, PACON 96. Recent Advances in Marine Science and Technology, Honolulu, pp 305-315

Hopley D, Smithers SG, Parnell KE (2007) The geomorphology of the Great Barrier Reef: development, diversity and change. Cambridge University Press, Cambridge, United Kingdom

Johnson-Roberson M, Pizarro O, Williams SB (2010) Generation and visualization of large scale 3D reconstructions from underwater robotics surveys. Journal of Field Robotics 27: 21-51

Kahng SE, Kelley CD (2007) Vertical zonation of megabenthic taxa on a deep photosynthetic reef (50-140 m) in the Au'au Channel, Hawaii. Coral Reefs 26: 679-687

Kahng SE, Garcia-Sais JR, Spalding HL, Brokovich E, Wagner D, Weil E, Hinderstein L, Toonen RJ (2010) Community ecology of mesophotic coral reef ecosystems. Coral Reefs 29: 255-275

Kleypas JA (1996) Coral reef development under naturally turbid conditions: fringing reefs near Broad Sound, Australia. Coral Reefs 15: 153-167 
Kirk TJO (1994) Light and photosynthesis in aquatic ecosystems. Cambridge

University Press, New York, United States

Lesser MP, Slattery M, Leichter JJ (2009) Ecology of mesophotic coral reefs. J Exp Mar Biol Ecol 375: 1-8

Liddell WD, Avery WE, Ohlhorst SL (1997) Patterns of benthic community structure, $10-250 \mathrm{~m}$, the Bahamas. Proc $8^{\text {th }}$ Int Coral Reef Symp 1: 437-442

Macintyre IG, Rutzler K, Norris JN, Smith KP, Cairns SD, Bucher KE, Steneck RS (1991) An early Holocene reef in the western Atlantic: submersible investigations of a deep relict reef off the west coast of Barbados, W.I. Coral Reefs 10: 167-174

Maragos JE, Jokiel PL (1986) Reef corals of Johnston Atoll: one of the world's most isolated reefs. Coral Reefs 4: 141-150

Ohlhorst SL, Liddell WD (1988) The effects of substrate microtopography on reef community structure at 60-120 m. Proc $8^{\text {th }}$ Int Coral Reef Symp 3: 355-360

Pyle RL, Earle JL, Greene BD (2008) Five new species of the damselfish genus Chromis (Perciformes: Labroidei: Pomacentridae) from deep coral reefs in the tropical western Pacific. Zootaxa 1671: 3-31

Scoffin TP, Tudhope AW (1985) Sedimentary environments of the central region of the Great Barrier Reef of Australia. Coral Reefs 4: 81-93

Thresher RE, Colin PL (1986) Trophic structure, diversity and abundance of fishes of the deep reef (30-300 m) at Enewetak, Marshall Islands. Bull Mar Sci 38: 253272

Van Woesik R, Done TJ (1997) Coral communities and reef growth in the southern Great Barrier Reef. Coral Reefs 16: 103-115

Veron JEN (2000) Corals of the world. Australian Institute of Marine Science, Townsville, Queensland, Australia

Webster JM, Davies PJ, Beaman RJ, Williams SB, Byrne M (2008) Evolution of drowned shelf-edge reefs in the GBR; implications for understanding abrupt climate change, coral reef response and modern deep water benthic habitats RV Southern Surveyor, voyage summary, Mar. Natl. Facil., Hobart, Tasmania, p18 (available at http://www.marine.csiro.au/nationalfacility/voyagedocs/2007/summarySS07-2007.pdf

Williams SB, Pizarro O, I, Webster JM, Beaman RJ, Mahon, Johnson-Roberson M, Bridge TCL (2008) Autonomous underwater vehicle-assisted surveying of drowned reefs on the shelf edge of the Great Barrier Reef, Australia. Journal of Field Robotics 27: 675-697 
Wolanksi E, Colin P, Naithani J, Deleersnijder E, Golbuu Y (2004) Large amplitude, leaky, island-generated, internal waves around Palau, Micronesia. Estuar Coast Shelf Sci 60: 705-716

Figures:

Fig. 1: Study site at Hydrographers Passage: (a) looking north-west. Major reef features are the "shoals" and submerged reefs at 50, 55, 80, 90100 and 130 m depth. Marilyn Shoal, which has previously been labelled in nautical charts, is shown for reference. Tidal channels bisect some reefs. The location of the AUV transect in the north of the study area is indicated in; (b) close up of the geomorphology along the AUV transect, looking south-east.

Fig. 2: Substrate composition along the AUV transect. Ten-point running means of substrate types were used for clear visual interpretation. Depth profile is shown to indicate changes in substrate relative to depth and geomorphic features

Fig. 3: Contribution of eight most abundant taxon classes to the five site groups identified using cluster analysis. Membership of taxon classes is shown in Appendix 1. The number of images in each site group is shown in brackets. Circles represent the mean abundance per image of each taxon class to each site group.

Fig. 4: Multi-dimensional scaling plot of sites (AUV images) based on the relative abundance of macrofauna. Colours correspond to site groups identified in cluster analysis ('Low macrofauna' sites not circled).

Fig. 5: Examples of site groups, showing (a) Dendronepthya colonies growing in soft substrate and the giant foraminifera Cycloclepeus on the sand sheet at $95 \mathrm{~m}$ depth; (b) diverse community of azooxanthellate filter-feeders (predominantly octocorals) growing on the crest of a sediment-covered limestone reef at $99 \mathrm{~m}$; (c) transitional community composed of both zooxanthellate corals and filter-feeding octocorals growing on a limestone reef wall, $62 \mathrm{~m}$; and (d) shallow-water community dominated by zooxanthellate octocorals, scleractinia and Carteriospongia, $55 \mathrm{~m}$.

Fig. 6: Depth zonation of three reef-associated site groups. The zooxanthellate group is dominant above $60 \mathrm{~m}$, the transitional group from $60-75 \mathrm{~m}$, and azooxanthellate filter-feeders are generally found in depths $>75 \mathrm{~m}$.

Fig. 7: Maps of the AUV transect showing: (a) location of the site groups ('low macrofauna' sites not shown); and (b) diversity ( $\mathrm{H}^{\text {') }}$ calculated using five-point running means.

Fig. 8: Diversity (H') (red), limestone (score on 5 point scale) (green) and rugosity index (RI) (blue). All plotted values are five-point running means along the AUV transect. 




b






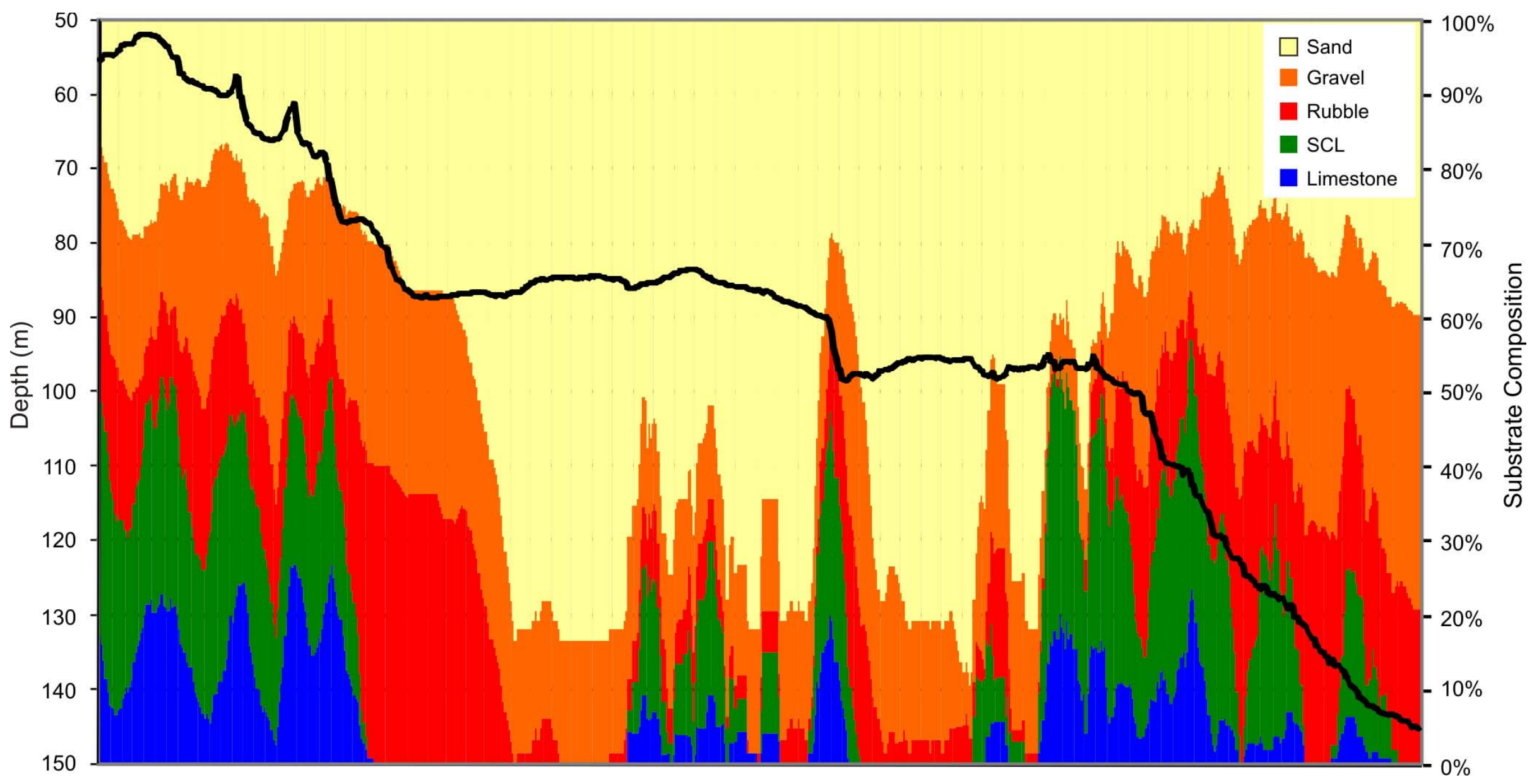




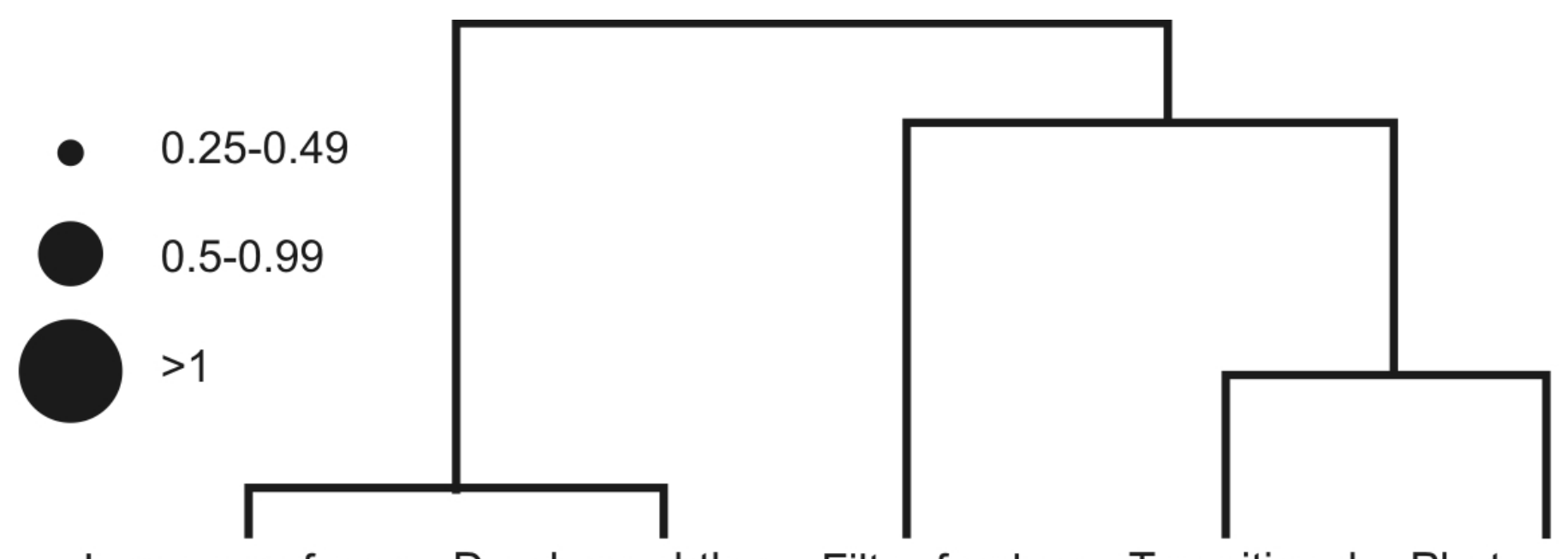

Taxon Class Low macrofauna (386)

Transitional Photosynthetic

Fan Gorgonian

Other Sponge

Carteriospongia

Antipatharia

Dendronephthya

Branching Scleractinia

Other Scleractinia

Zoox. Octocoral

(202)

(68)
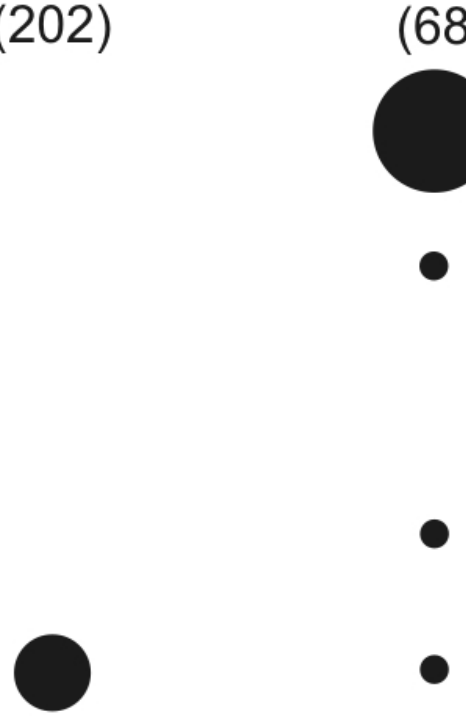

(23)
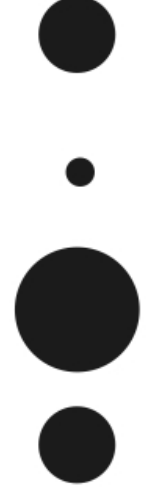

(39)
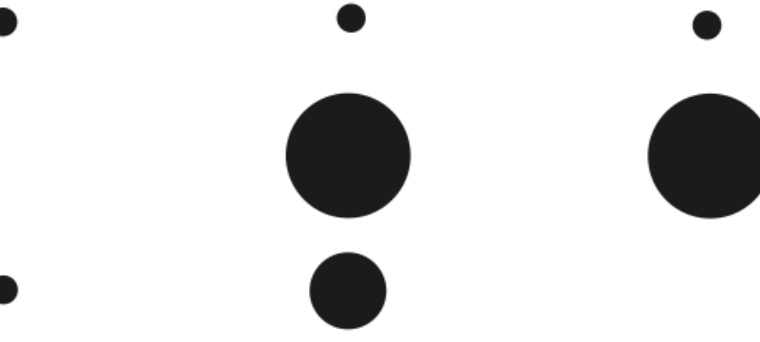

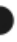




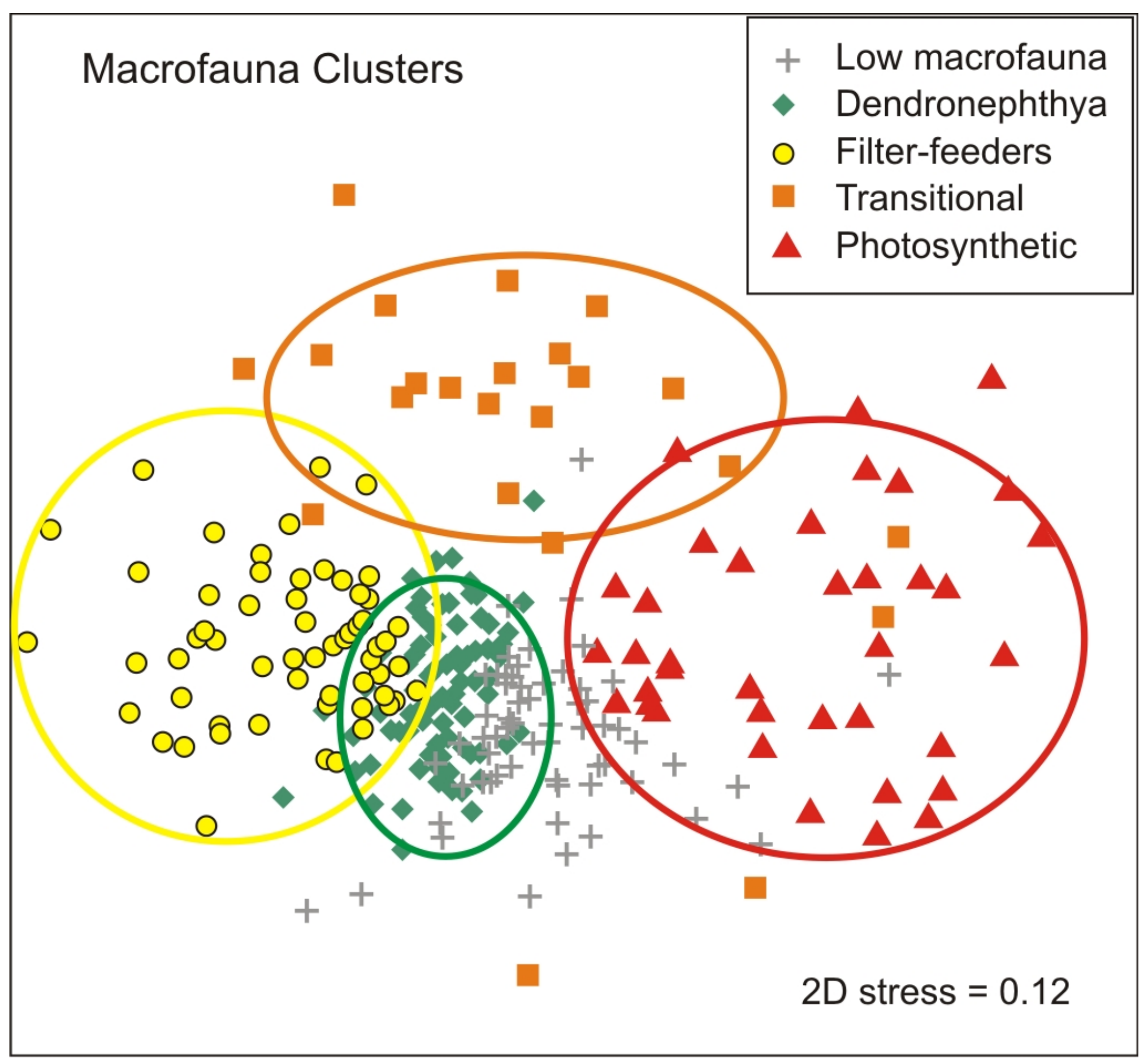






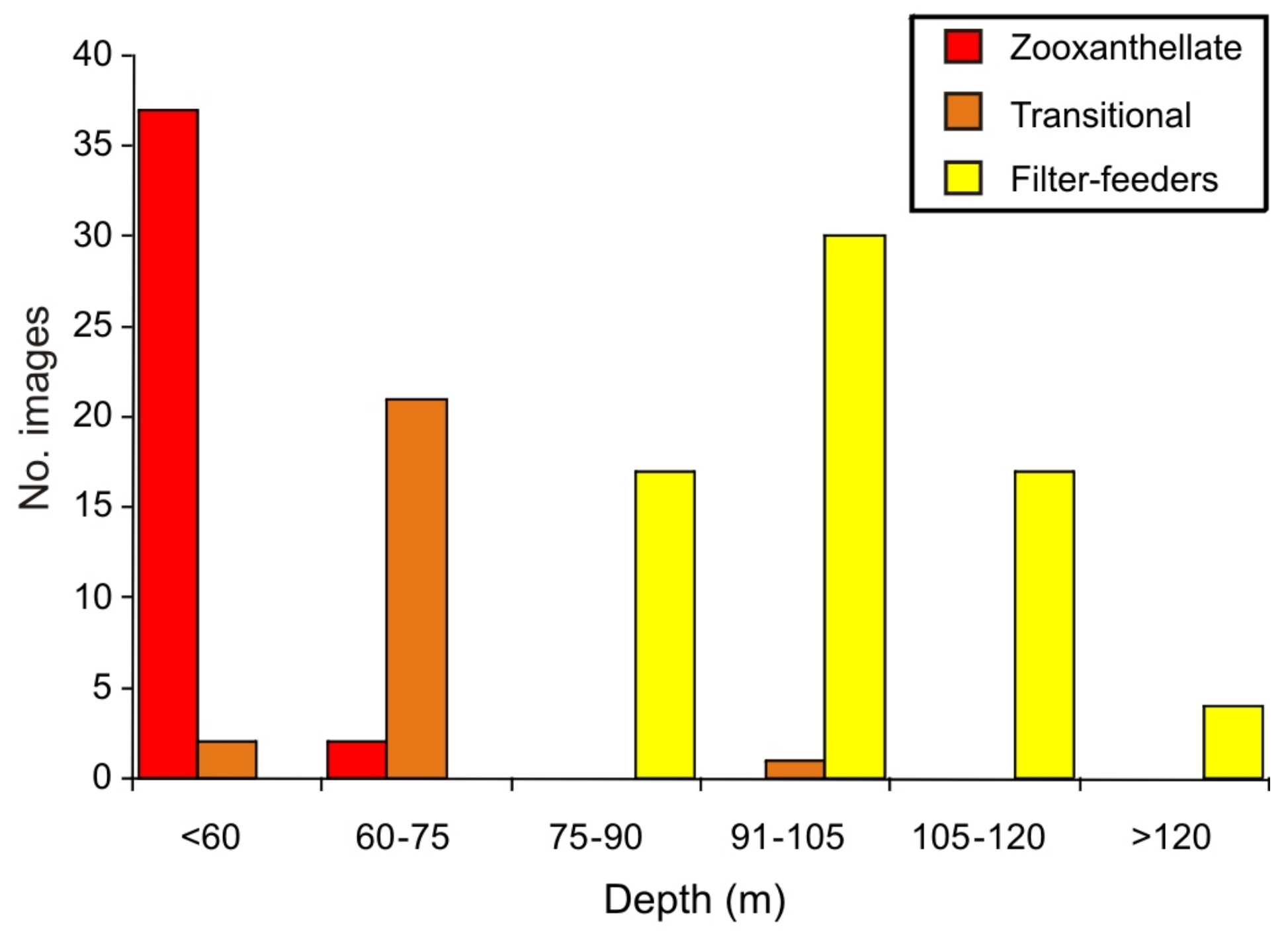






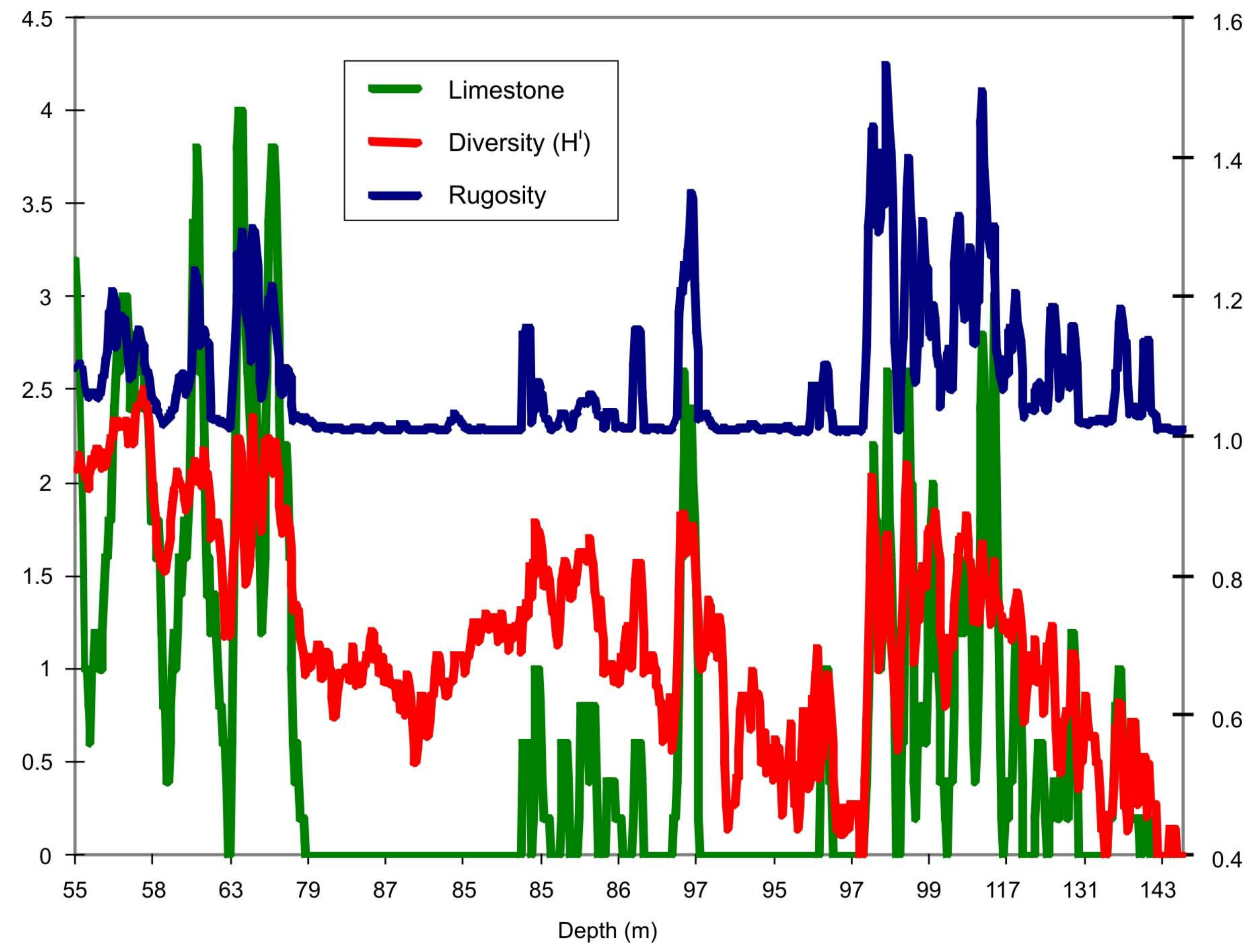


Table 1: Definitions of substrate types.

\begin{tabular}{ll}
\hline Name & Description \\
\hline Sand & $\begin{array}{l}\text { Unable to distinguish individual grains in images; estimated grainsize <2 } \\
\text { mm. } \\
\text { Gravel }\end{array}$ \\
$\begin{array}{l}\text { Larger than sand but smaller than rubble; estimated grainsize } ~ 3-30 \mathrm{~mm} . \\
\text { Rubble } \\
\begin{array}{l}\text { Clasts }>30 \mathrm{~mm} \text { grainsize but not firmly attached to the substrate. } \\
\text { (SCL) }\end{array}\end{array}$ \\
$\begin{array}{l}\text { Limestone which has been covered by sediment but appears hard } \\
\text { underneath. }\end{array}$ \\
\hline
\end{tabular}

Table 2: Mean values for abiotic variables and diversity for each site group. Standard deviation is also shown for rugosity index and slope. Values for the five substrate types were calculated using the $0-5$ relative abundance scale.

\begin{tabular}{llllll}
\hline Site Group & $\mathbf{1}$ & $\mathbf{2}$ & $\mathbf{3}$ & $\mathbf{4}$ & \multicolumn{1}{c}{$\mathbf{5}$} \\
\hline Depth (m) & 91 & 103 & 100 & 67 & 54 \\
Rugosity Index & $1.02 \pm 0.04$ & $1.07 \pm 0.11$ & $1.31 \pm 0.23$ & $1.24 \pm 0.16$ & $1.12 \pm 0.07$ \\
Slope ( $\left.{ }^{\circ}\right)$ & $5 \pm 4$ & $8 \pm 9$ & $22 \pm 18$ & $21 \pm 13$ & $6 \pm 6$ \\
Sand & 4.3 & 3.9 & 3.0 & 2.2 & 3.2 \\
Gravel & 2.1 & 2.3 & 1.7 & 1.7 & 2.4 \\
Rubble & 1.5 & 1.6 & 1.3 & 1.2 & 1.7 \\
Sediment-Covered Limestone & 0.6 & 1.4 & 3.4 & 3.2 & 3.4 \\
Limestone & 0.3 & 0.5 & 1.9 & 3.2 & 2.3 \\
Diversity (H') & 0.1 & 0.6 & 1.2 & 1.4 & 1.3 \\
\hline
\end{tabular}


Appendix: Taxa included in taxon matrix collected during the study. "Taxon Category" lists the 27 categories under which data were analysed for statistical analysis. To clearly display broad taxon classes and their relative importance to different site groups, these 27 categories were condensed into Taxon Classes, seen in column 2. "Taxa included" shows the taxa that were able to be identified, and which group they were included in. Many taxa were unable to be resolved to species level from the AUV images, particularly taxa such as octocorals, which require examination of sclerites for accurate identification, even to generic level.

\begin{tabular}{|c|c|c|}
\hline Taxon Category & Taxon Class (Fig.3) & Taxa Included \\
\hline Carteriospongia & Carteriospongia & Carteriospongia foliascens? \\
\hline Light brown thinly branching & & \\
\hline sponge & Other Sponge & ID unknown \\
\hline Purple Vase Sponge & Other Sponge & ID unknown \\
\hline Encrusting Sponge & Other Sponge & ID unknown \\
\hline 3D Sponge & Other Sponge & $\begin{array}{l}\text { Diverse taxa, ID unknown } \\
\text { Several encrusting and plating }\end{array}$ \\
\hline Montipora & Other Scleractinia & $\begin{array}{l}\text { species of Montipora } \\
\text { Multiple species, ID not possible }\end{array}$ \\
\hline Leptoseris & Other Scleractinia & $\begin{array}{l}\text { from AUV images } \\
\text { Multiple species, ID not possible }\end{array}$ \\
\hline Echinophyllia (Mycedium) & Other Scleractinia & $\begin{array}{l}\text { from AUV images } \\
\text { Fungia } s p \text {. and Diaseris distorta }\end{array}$ \\
\hline Fungiid & Other Scleractinia & $\begin{array}{l}\text { identified in dredge samples } \\
\text { Plating and branching Acropora, } \\
\text { Pocillopora, and Seriatopora } \\
\text { hystrix identified from dredge }\end{array}$ \\
\hline Branching Coral & Branching Scleractinia & samples \\
\hline Plating Coral & Other Scleractinia & ID unknown \\
\hline Encrusting/Massive Coral & Other Scleractinia & ID unknown \\
\hline Antipathes & Antipatharia & ID unknown \\
\hline Cirrhipathes & Antipatharia & ID unknown \\
\hline Stichopathes & Antipatharia & ID unknown \\
\hline Other Antipatharian & Antipatharia & ID unknown \\
\hline Cespitularia & Zoox Octocoral & $\begin{array}{l}\text { ID unknown } \\
\text { Sarcophyton, Lobophyton, }\end{array}$ \\
\hline Alcyoniid & Zoox Octocoral & Sinularia \\
\hline Other zooxanthellate octocoral & Zoox Octocoral & Xeniidae \\
\hline Dendronephthya & Dendronephthya & $\begin{array}{l}\text { Species ID unknown } \\
\text { Annella most abundant. } \\
\text { Siphonogorgia, Chironepthya, } \\
\text { Echinogorgia, Zignisis also }\end{array}$ \\
\hline Fan Gorgonian & Fan Gorgonian & identified from dredge samples \\
\hline Branching Ellisellid & Ellisellid (not shown) & Ellisella \\
\hline Non-branching Ellisellid & Ellisellid (not shown) & Viminella, Junceella \\
\hline Other Gorgonian & Other Gorgonian (not shown) & $\begin{array}{l}\text { ID unknown } \\
\text { Acrozoanthus, other IDs }\end{array}$ \\
\hline Zoanthid & Zoanthid (not shown) & unknown \\
\hline Hydroid & Hydroid (not shown) & ID unknown \\
\hline Crinoid & Crinoid (not shown) & Several taxa, IDs unknown \\
\hline
\end{tabular}

